\title{
Blood on the Snow
}

\section{The Carpathian Winter War of 1915}

Graydon A. Tunstall

"With bold, powerful brush strokes, Tunstall paints a picture of horrendous death in the Carpathian Mountains. Austria-Hungary and Russia each lost about one million men, making the battle more costly than the better known ones of Verdun and the Somme 1916. Meticulously researched and well written, this is military history at its finest. A must read." -Holger H. Herwig, author of The Marne, 1914

"Snow falls on the mountains, wolves howl in the distance, and two doomed armies learn the truth of the old adage, 'there is no enemy more formidable than nature.' An essential book for all World War I libraries."-Robert M. Citino, author of The German Way of War

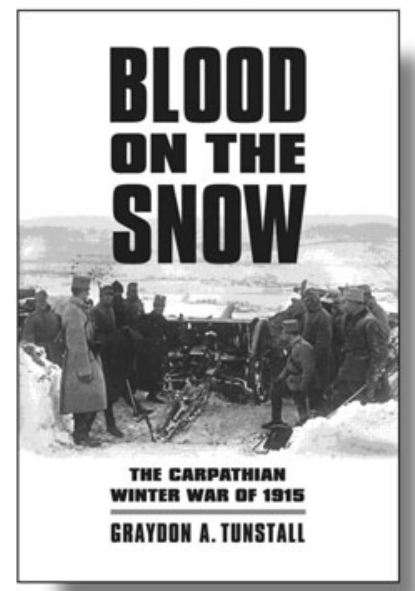

320 pages, 20 photographs, Cloth $\$ 29.95$

\section{University Press of Kansas}

Phone (785) 864-4155 • Fax (785) 864-4586 • www.kansaspress.ku.edu 
Cover Design: Original design by Andrew Esson, Baseline Arts Ltd, Oxford. 2010 design by Daniel Pinkerton

Cover Art: Newly arrived Jewish DPs from Eastern Europe are gathered near the Enns River in Austria (1946).

Source: United States Holocaust Memorial Museum

Composition: TechSet

Printer: The Sheridan Press

Text: $\quad$ Minion Pro 


\section{AUSTRIAN HISTORY YEARBOOK \\ VOLUME XLI • 2010}

David S. Luft

Howard Louthan

David C. Mengel

James D. Mixson

Christopher Ocker

Maria Golubeva

Miroslav Šedivý

Andriy Zayarnyuk

Alexander Vari

Britta I. McEwen

Tara Zahra

Andrew E. Harrod
Editors' Notes

Twenty-Fifth Annual Robert A. Kann Memorial Lecture

Austrian Intellectual History before the Liberal Era: Grillparzer, Stifter, and Bolzano

\section{Forum}

\section{Religion and Reform in "Late Medieval" Central Europe}

Introduction

Emperor Charles IV (1346-1378) as the Architect of Local Religion in Prague

Contesting Authority and Community: Models and Practices of Monastic Reform in Late Medieval Central Europe

The Birth of an Empire of Two Churches: Church Property, Theologians, and the League of Schmalkalden

\section{Articles}

Competent to Rule?: Galeazzo Gualdo Priorato and a Secular View of Politics in Habsburg Dynastic History

Metternich and the Syrian Question: 1840-1841

Mapping Identities: The Popular Base of Galician Russophilism in the 1890s

Bullfights in Budapest: City Marketing, Moral Panics, and Nationalism in Turn-of-the-Century Hungary

Welfare and Eugenics: Julius Tandler's Rassenhygienische Vision for Interwar Vienna

"Prisoners of the Postwar": Expellees, Displaced Persons, and Jews in Austria after World War II

Austrian Neutrality: The Early Years, 1955-1958

plus 42 book reviews 